\title{
THE INTERDEPENDENCE BETWEEN TOURISM AND INNOVATION ACTIVITY IN THE WESTERN BORDERLANDS OF RUSSIA
}

\author{
Vasilisa GOROCHNAYA \\ Southern Federal University, Institute of Psychology and Educational Sciences, Nagibina av., 14, 344006, Rostov-on-Don, Russian Federation; \\ Immanuel Kant Baltic Federal University, Institute of Environmental Management, \\ Urban Development and Spatial Planning, Zoologicheskaya Str., 2, 236016, Kaliningrad, Russian Federation, e-mail: tunduk@ hotmail.com
}

\section{Andrey MIKHAYLOV*}

Institute of Geography of the Russian Academy of Sciences, Laboratory of Geopolitical Studies, Staromonetny pereulok 9, 119017 Moscow, Russian Federation; Immanuel Kant Baltic Federal University, Institute of Regional Studies, Innovation Geography Laboratory, Gaidara Str., 6, 236029, Kaliningrad, Russian Federation, e-mail: mikhailov.andrey@yahoo.com

\author{
Angelina PLOTNIKOVA \\ Immanuel Kant Baltic Federal University, Institute of Regional Studies, Innovation Geography \\ Laboratory, Gaidara Str., 6, 236029, Kaliningrad, Russian Federation, e-mail: a.plotnikova.1416@gmail.com
}

Anna MIKHAYLOVA

Immanuel Kant Baltic Federal University, Institute of Regional Studies, Center for Baltic Studies, Gaidara Str., 6, 236029, Kaliningrad, Russian Federation, e-mail: tikhonova.1989@mail.ru

\begin{abstract}
Citation: Gorochnaya V., Mikhaylov A., Plotnikova A., \& Mikhaylova A. (2021). THE INTERDEPENDENCE BETWEEN TOURISM AND INNOVATION ACTIVITY IN THE WESTERN BORDERLANDS OF RUSSIA. GeoJournal of Tourism and Geosites, 34(1), 147-154. https://doi.org/10.30892/gtg.34119-630
\end{abstract}

\begin{abstract}
An intensive movement of people, which is typical in areas with strong tourism industry, is perceived to provide numerous positive externalities with regards to the diversity of cultures, ideas, and knowledge. Border regions act as natural contact zones experiencing the influx of tourists across borders. The borderland is expected to benefit from their geolocation and intensive cross-border cooperation, acting as testing grounds for external innovations. The article is designed to test the interdependence between the tourism industry and innovation activity in the borderland The study focuses on the western border regions of Russia, which is a highly divergent area in terms of socio-economic development and experiences challenging times in the context of geo-economic turbulence after 2014. By using the statistical research method, the study develops on evaluating the dynamics of indicators for tourism industry development and innovation activity. The eight-year period of 2012-2019 is applied for taking into account the lag in innovation performance resulting from the positive externalities of tourism. Results show that the growth in tourism industry and innovation activity of found in regions with intensive public expenditure on large-scale infrastructural projects.
\end{abstract}

Key words: innovation activity, tourism industry, innovation security, border regions, borderland, Russia

$* * * * *$

\section{INTRODUCTION}

There are numerous regions and countries around the globe whose socio-economic development depends on tourism. According to the World Travel and Tourism Council (WTTC) annual report of 2020, the tourism industry contributes to 10.3\% of global economy GDP and acts as one of the world's largest employment sectors supporting 330 million jobs as of 2019. The country level data suggests that individual countries' economic dependence on tourism reaches over 50\% of GDP, e.g. Macau $-91.3 \%$, Aruba - 73.6\%, British Virgin Islands - 57.0\%, Maldives $-56.6 \%$, US Virgin Islands - 55,5\% (WTTC, 2020). Surely, the COVID-19 pandemic has affected the tourism industry, causing many SMEs and even large businesses go bankrupt. The United Nations World Tourism Organization (UNWTO, 2021) reports of a significant drop in international arrivals by $74 \%$ in 2020, predicting a long-lasting impact of the pandemic - the pre-pandemic level of tourism activity is not expected before 2023. With that, the optimistic projections suggest a gradual recovery and an increasing growth of domestic tourism after the lockdown (Assaf and Scuderi, 2020). Moreover, the resilient strategies of tourism are highlighting its complex cross-industry nature and diversification spread on to (un)related variety of economy sectors (Romão, 2020).

Most of the popular tourist destinations have developed regional clusters of related activities that boost the development of catering, entertainment, wellness, crafts, cultural facilities, transportation, farming, education services and other complementary activities (Sigurardottir and Steinthorsson, 2018; Vorobiova et al., 2019; Mauri and Turci, 2018). This cross-sectoral "fertilization" inevitably increases economic resilience. The inflow of tourists facilitates entrepreneurship and favors the diversity of economic activities (Lejárraga and Walkenhorst, 2013). While the correlation between tourism intensity and economic performance is extensively monitored and widely documented, the interdependence between the tourism and innovation activity is far less studied (according to Gomezelj (2016), these are only $12.4 \%$ of all published research on tourism). On the one hand, the innovation performance studies focus on the tourism industry itself. These are predominantly incremental and adaptive innovations that improve certain attributes and functions but rarely create any disruptive effect (Panfiluk, 2021). For instance, Brandão et al. (2019) note that innovation towards the tourism products is particularly relevant considering the change in consumer behavior, thus, are responsive to modern customer expectations. Digitalization is one of the vivid examples (Happ and Ivancsóné Horváth, 2020), starting from online and mobile bookings of hotels, travel tickets, and restaurants on to customized offerings of travel packages. There is a global trend on consumer-driven and environmentally friendly innovations in tourism and hospitality that cover the diversity of interrelated services and products combined in a single quality perception of a tourist about the 
destination and the local community (Pikkemaat et al., 2019). For the customer tourist experience is being composed of market offerings (products and services) from multiple providers, the tourism industry is highly interested in developing the regional market along with other "interwoven" economy sectors and the public environment (Hoarau, 2014).

On the other hand, the tourism is, therefore, found to be the trigger of regional innovation activity. Ozseker (2019) argues that the configuration and the development trajectory of a local innovation system can be transformed by the tourism industry and the tourism innovation systems (TIS). The TIS is defined as "...the parts and aspects of the economic structure and institutional set-up affecting learning and innovation in tourism firms" (Sundbo et al., 2007: 93). The organizations in tourism destinations tend to be highly networked, forming a "loosely articulated groups of independent suppliers linked together to deliver the overall product" (Scott et al., 2008: 171). Moreover, Verreynne et al. (2019) clarified that tourism market does incorporate firms that are not limited to those generally classified as tourism firms and expand to the related sub-sectors. Therefore, the innovation activity is facilitated by firms within and outside the tourism industry.

Of particular interest to this study is the role of tourism in driving the innovation activity of border regions. The regional development strategies of the borderland inevitably focus on cross-border cooperation while balancing between the contact and barrier function of the border (Kolosov et al., 2016). By focusing on international markets with a wide network of inter-organizational and cross-industry ties the tourism industry companies can foster innovation and change (Brandão et al., 2018). The diversity of cultures, ideas, and knowledge "spilling" over the border support the absorption of new technologies and innovation. The border regions could act as testing grounds collecting the tacit knowledge and adopting the foreign-born innovations to the national institutional context (Mikhaylov et al., 2020). As noted by Zach and Hill (2017), networking and boundary spanning favors the in-flow of new ideas, while close collaboration facilitates the implementation and application of the shared knowledge. In recent years, the development of border regions via the implementation of crossborder cooperation in tourism has received an increased attention (Nilsson et al., 2010; Rajčáková and Švecová, 2013; Vaishar et al., 2013). Scholars indicate that border areas are better aligned with the needs of tourists and are prompt to response with market-specific innovations (Weidenfeld, 2018). Moreover, the international movement of people (and tourist mobility in particular) and temporary face-to-face interactions between knowledge receivers (residents) and providers (tourists) is much more intensive at the border regions, where tourism plays an essential role in disseminating knowledge and innovations (Weidenfeld, 2013). The study of Makkonen et al. (2018) presents the classification of the cross-border knowledge flows, distinguishing between the intentional (knowledge transfer) and unintentional (knowledge spillovers) knowledge sharing. The authors conclude that cross-border tourism can address the issues of peripherality by achieving synergies with neighboring territories. In this paper we aim to analyze the co-development of both tourism and innovation activity in the borderland based on empirical data from the western border regions of Russia. In the next section we describe the methodology for our study and Section 3 provides our empirical results. The paper closes with some discussion and conclusions.

\section{MATERIALS AND METHODS}

The study area covers 15 western border regions of Russia, listed from north to south: Murmansk region, Republic of Karelia, Leningrad region, St. Petersburg city, Pskov region, Kaliningrad region, Smolensk region, Bryansk region, Kursk region, Belgorod region, Voronezh region, Rostov region, Krasnodar region, Republic of Crimea, and Sevastopol (Figure 1). These regions are the contact zones with eight countries: the European Union member states (Finland, Estonia, Latvia, as well as Lithuania and Poland in the case of exclave territory of Kaliningrad region), Norway, Belarus, and Ukraine.

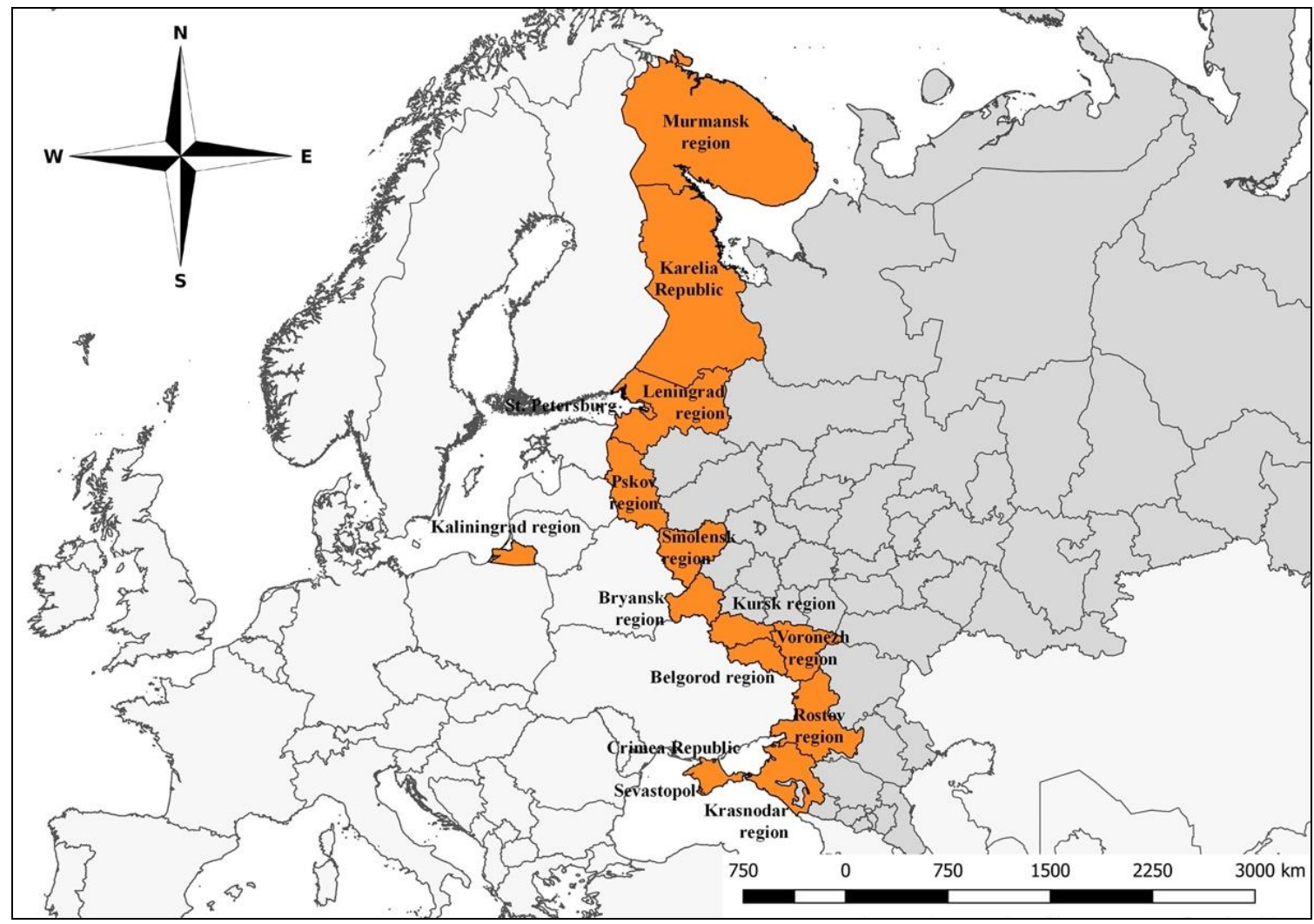

Figure 1. The location of the study area (Source: developed by the authors)

The Federal State Statistics Service of the Russian Federation (Rosstat, URL: www.gks.ru) is used as a primary source of data. The research design is structured into three stages: 1) Measuring the dynamics of institutional density - the number and diversity of tourism- 
related (Accommodation facilities, Sanatoriums and resorts, Travel agencies) and research-intensive (Research organizations, Share of innovative organizations) organizations. The institutional density is determined as the primary indicator of the tourism industry development and its possible impact on the regional economy; 2) Measuring the performance dynamics - the output of the tourism sector (Tourist packages sold, People sent on tours, Persons placed in collective accommodation facilities, Persons placed in health resort organizations) and the indicators of the innovation activity (Internal research and development costs, Technology development costs, Number of technologies used, Volume of innovative products, Share of innovative products in GRP); 3) Measuring the relationship between tourism and innovation activity using the average annual growth rate performance. The data archive depth covers eight years - from 2012 to 2019 . Due to inconsistency in the statistical data series the dates of individual indicator values were taken for the closest available dates. Therefore, some values start from 2010 or 2011 . The eight-years period considered ensures detection of both the long-term trends and the changes after geoeconomic turbulence started in 2014 after the geopolitical shocks at Ukrainian-Russian border.

The data on both tourism and innovation development is assessed in absolute values and analyzed via annual growth rates. The comparison between tourism and innovation activity is provided via relation of the accounted average geometrical growth rates. Due to the general lag period of implementing innovations, the formula used accounts for the indicators on innovation activity with a one-year lag as compared to the tourism development (i.e. the time lag between industry and innovation is considered to be equal to 1 year):

$$
I=\frac{\sqrt[n]{\boldsymbol{V}_{0 t} \cdot \cdots \cdot \boldsymbol{V}_{n t}}}{\sqrt[m]{\boldsymbol{V}_{0 t-1} \cdot \cdots \cdot \boldsymbol{V}_{m t-1}}}
$$

$I$ - the index reflecting the relation of tourism development against innovation activity in the previous period; $n$ - the number of indicators accounted for tourism industry development; $m$ - the number of indicators accounted for innovation activity development; $v_{n t}-$ the annual growth rate of the $\mathrm{n}_{\text {th }}$ indicator on tourism industry in the year $t ; v_{m t-1}$ - the annual growth rate of the $m_{t h}$ indicator on innovation activity in the year $t-1$. The average indicator values are calculated for every region, for all the regions in the given year (to indicate the general dynamic changes for all the western borderlands), for the whole period of 2011-2019 (related to 2010-2018), and for the period 20152019 (related to 2014-2018) - in order to point out the specifics of this period after the beginning of geo-economic turbulence.

\section{RESEARCH RESULTS}

The institutional density of tourism industry and innovation activity

The statistical assessment of the institutional density of the western border regions of Russia in absolute values marks the general congruence between the tourism industry and the innovation sector development of the most advanced regions. Not only Krasnodar region as the center of coastal tourism at the South, but other regions with developed innovational environment are among the leaders of tourism industry development (Figure 2). The prevailing role of St. Petersburg as both the 'culture capital' of Russia and large science \& technology center is discovered as expected, but the development dynamics of organizations is independent: while the number of sanatoriums and resorts is in decline, the number of travel agencies and accommodation facilities multiplies, that reflects the change of the touristic profile of the city. This trend takes place against the background of reducing number of research organizations and the declining share of innovative organizations in the recent years.

It is noticeable that both vectors of growing and reducing research and innovative organizations predominantly correspond the similar dynamics found for travel agencies and in a lesser extent of accommodation facilities, sanatoriums and resorts.

The calculation of the composite index demonstrates that in most of the regions the development dynamics in the number of research (knowledge-generating) and innovation (knowledge commercialization) organizations are generally in proportion with the tourism industry dynamics - most values equal or are very close to 1 . The multiplicative superior growth of tourism institutional density is noted in 2014 2016, which is the period of the most geo-political tension at the western borderland of Russia, followed by the proportional co-development of innovation sector with the two-year wave length oscillation (Table 1).

\begin{tabular}{|l|c|c|c|c|c|c|c|c|c|c|}
\hline Year / Region & $\mathbf{2 0 1 2}$ & $\mathbf{2 0 1 3}$ & $\mathbf{2 0 1 4}$ & $\mathbf{2 0 1 5}$ & $\mathbf{2 0 1 6}$ & $\mathbf{2 0 1 7}$ & $\mathbf{2 0 1 8}$ & $\mathbf{2 0 1 9}$ & $\mathbf{2 0 1 2 - 2 0 1 9}$ & $\mathbf{2 0 1 5 - 2 0 1 9}$ \\
\hline Murmansk region & 1.15 & 0.90 & 0.85 & 1.09 & 1.01 & 1.43 & 0.93 & 0.91 & $\mathbf{1 . 0 2}$ & $\mathbf{1 . 0 6}$ \\
\hline Republic of Karelia & 0.87 & 0.93 & 1.21 & 1.15 & 1.10 & 0.97 & 1.48 & 0.78 & $\mathbf{1 . 0 4}$ & $\mathbf{1 . 0 7}$ \\
\hline St. Petersburg & 0.92 & 1.05 & 0.91 & 1.15 & 1.34 & 1.43 & 0.94 & 0.91 & $\mathbf{1 . 0 6}$ & $\mathbf{1 . 1 3}$ \\
\hline Leningrad region & 1.02 & 0.93 & 1.11 & 1.09 & 0.84 & 1.33 & 1.02 & 1.08 & $\mathbf{1 . 0 4}$ & $\mathbf{1 . 0 6}$ \\
\hline Kaliningrad region & 1.21 & 0.83 & 0.91 & 1.87 & 0.62 & 0.98 & 1.33 & 0.85 & $\mathbf{1 . 0 2}$ & $\mathbf{1 . 0 5}$ \\
\hline Pskov region & 1.08 & 1.07 & 1.18 & 0.96 & 1.00 & 0.94 & 1.12 & 1.12 & $\mathbf{1 . 0 6}$ & $\mathbf{1 . 0 3}$ \\
\hline Smolensk region & 0.94 & 1.06 & 0.96 & 1.07 & 0.76 & 1.10 & 1.09 & 0.99 & $\mathbf{0 . 9 9}$ & $\mathbf{0 . 9 9}$ \\
\hline Bryansk region & 0.85 & 1.10 & 1.11 & 0.96 & 1.17 & 1.09 & 1.11 & 1.05 & $\mathbf{1 . 0 5}$ & $\mathbf{1 . 0 7}$ \\
\hline Kursk region & 0.66 & 1.07 & 1.20 & 1.16 & 1.13 & 1.04 & 1.19 & 0.96 & $\mathbf{1 . 0 3}$ & $\mathbf{1 . 0 9}$ \\
\hline Belgorod region & 0.92 & 1.32 & 0.91 & 1.10 & 0.70 & 1.22 & 1.07 & 0.90 & $\mathbf{1 . 0 0}$ & $\mathbf{0 . 9 8}$ \\
\hline Voronezh region & 0.92 & 1.04 & 0.99 & 1.39 & 0.77 & 1.12 & 0.97 & 0.93 & $\mathbf{1 . 0 0}$ & $\mathbf{1 . 0 1}$ \\
\hline Rostov region & 1.00 & 0.92 & 1.12 & 0.95 & 0.82 & 1.15 & 1.12 & 0.98 & $\mathbf{1 . 0 0}$ & $\mathbf{1 . 0 0}$ \\
\hline Krasnodar region & 1.03 & 0.90 & 1.12 & 1.04 & 0.89 & 0.95 & 0.99 & 1.11 & $\mathbf{1 . 0 0}$ & $\mathbf{0 . 9 9}$ \\
\hline Republic of Crimea & - & - & - & - & 2.24 & 1.25 & 0.88 & 1.19 & $\mathbf{1 . 3 1}$ & $\mathbf{1 . 3 1}$ \\
\hline Sevastopol & - & - & - & - & 4.35 & 0.21 & 0.92 & 1.04 & $\mathbf{0 . 9 7}$ & $\mathbf{0 . 9 7}$ \\
\hline Average & $\mathbf{0 . 9 6}$ & $\mathbf{1 . 0 0}$ & $\mathbf{1 . 0 4}$ & $\mathbf{1 . 1 3}$ & $\mathbf{1 . 0 7}$ & $\mathbf{1 . 0 1}$ & $\mathbf{1 . 0 7}$ & $\mathbf{0 . 9 8}$ & $\mathbf{1 . 0 3}$ & $\mathbf{1 . 0 5}$ \\
\hline
\end{tabular}

Table 1. The interdependence of tourism and innovation sectors growth rates by institutional density (Data source: developed by the authors)

Note: the index is based on the following data: in the numerator are the growth rates of indicators - the number of travel agencies, the number of collective accommodation facilities, the number of sanatorium-resort organizations; in the denominator are the growth rates of indicators - the number of research organizations, the share of innovative organizations in the total number of organizations.

The most extensive growth of tourism industry in relation to innovation activity for the whole period is typical for St. Petersburg, Pskov and Bryansk regions, and in the less extent for the Republic of Karelia and Leningrad region (the highest values for the Republic of Crimea is due to its inclusion into Russian economic and legal system that caused the need for transformation of the previous regional system of tourism business and its reorientation to Russian demand in the conditions of economic sanctions). The values of the indicator for the post- 
turbulent period are generally higher, that marks the trend to an active development of tourism. The only exception is Smolensk region, and in Belgorod region the development of tourism is not as fast and intensive as the innovation growth of the region. It is noticeable that in the last two years the value of indicator is below 1 in both northern and southern regions (except Krasnodar region). This recent trend can mark the need for new impetus from innovation environment for the further qualitative growth of tourism industry.
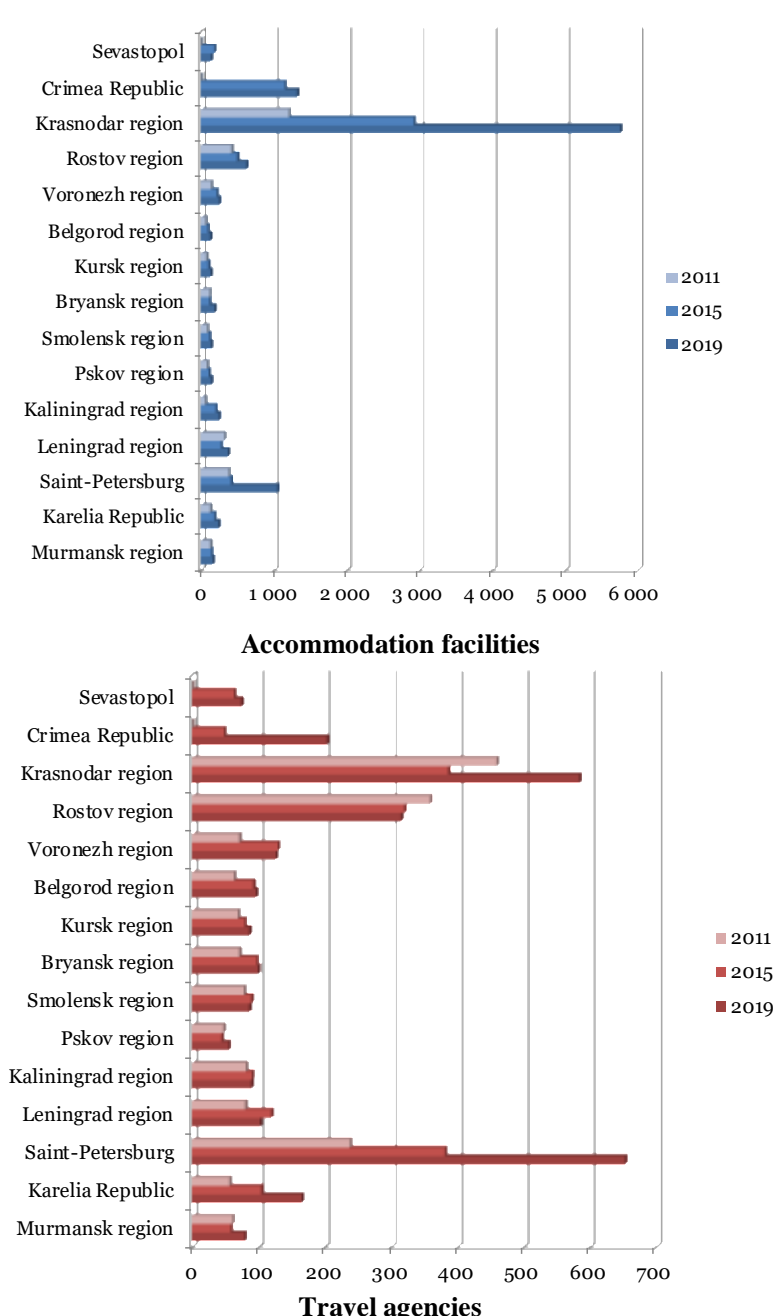

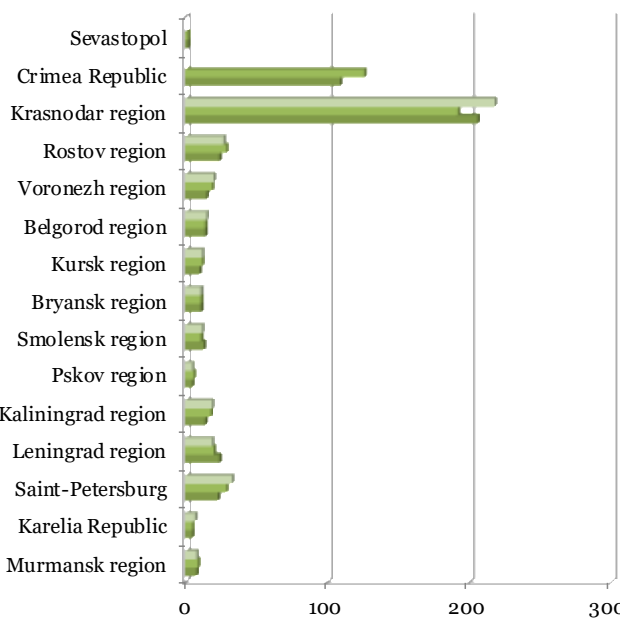

Sanatoriums and resorts

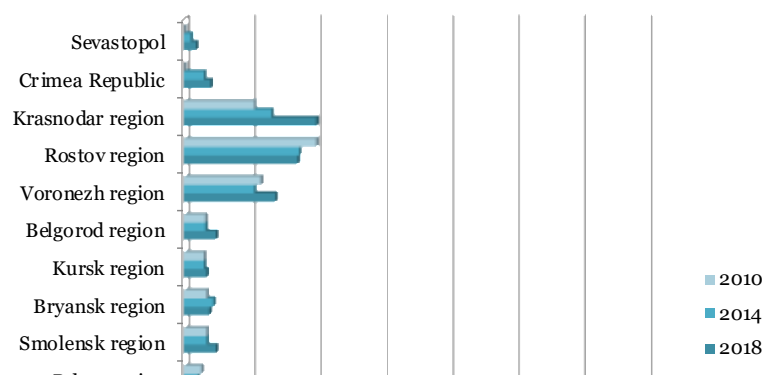

Pskov region

Kaliningrad region

Leningrad region

Saint-Petersburg

Karelia Republic

Murmansk region

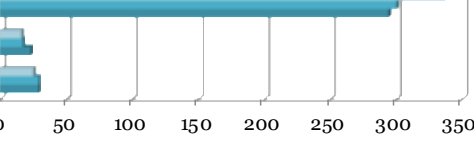

Research organizations
2011

$\square 2015$

- 2019

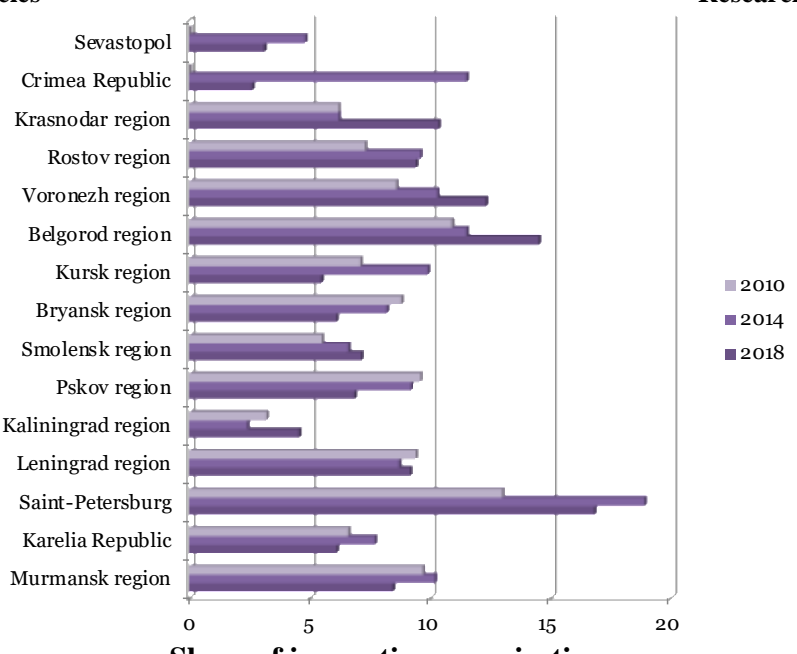

Share of innovative organizations

Figure 2. Institutional density dynamics of tourism and innovation activity (Source: developed by the authors)

The tourism sector performance and the innovation activity indicators

The performance indicators predominantly duplicate the picture of institutional density. There is a notable difference and a clearly reflected division of function between recreational and healthcare tourism in the southern coastal regions against the historical and cultural tourism in the north (including the 'northern capital' of Russia - the Saint-Petersburg). The data also reflects the growing role of Kaliningrad and Leningrad regions (Figure 3). The dynamics of expenditures on innovations, their use and production in comparison to tourism industry performance indicate the lack of innovations in the Republic of Crimea and the need for modernization of its infrastructure and development internal potential for creating and conducting the innovation adapted for the local use (Figure 4). 
Generally, there is less divergence in use of innovations than in their production and expenditures. This could indicate the lack of internal financial and human resources in small regions needing the cross-regional technological projects with the territorial division of labor.

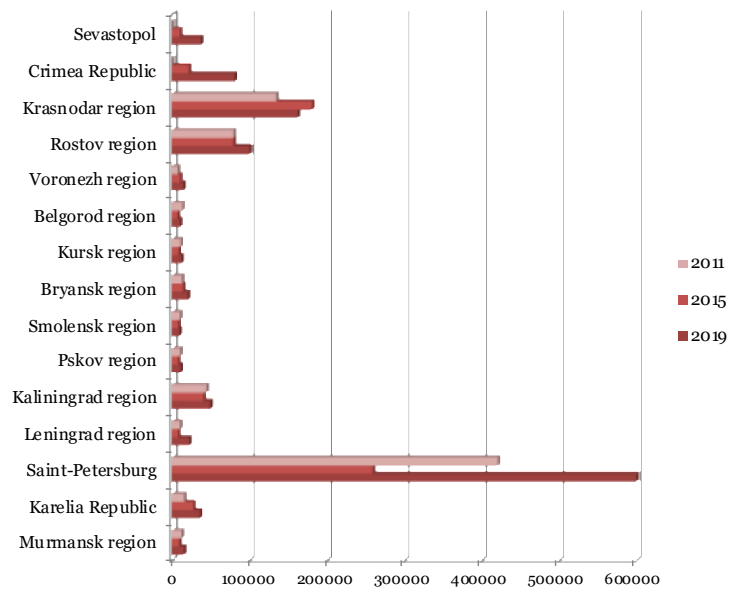

Tourist packages sold, units

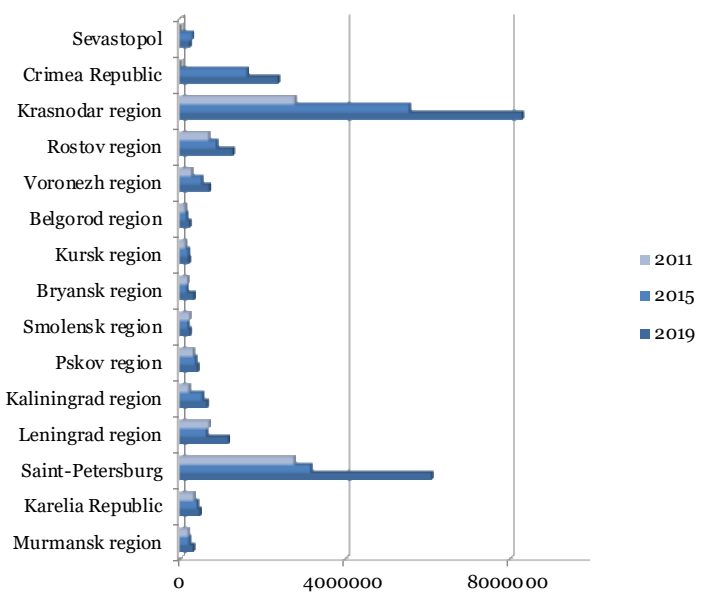

Persons placed in collective accommodation facilities, people

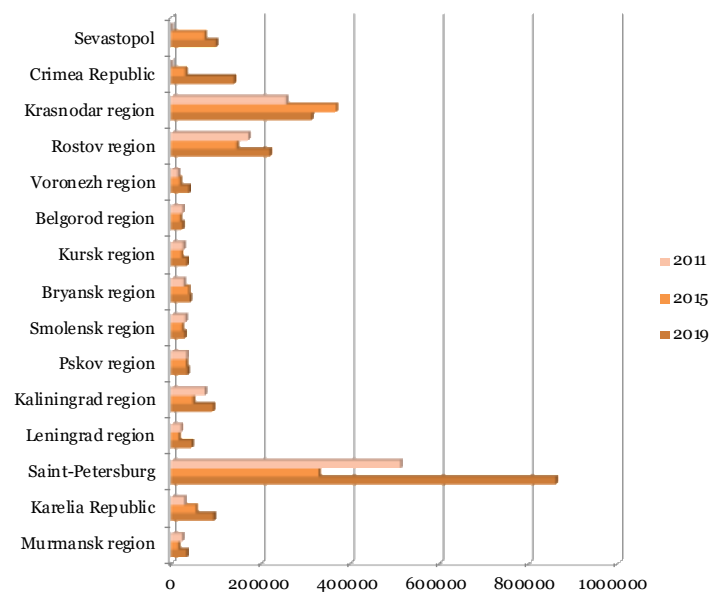

People sent on tours, people

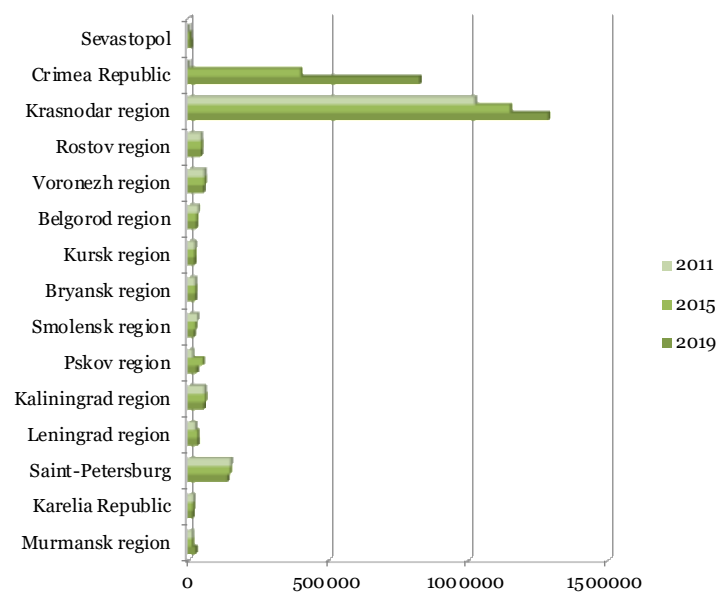

Persons placed in health resort organizations, people Figure 3. Dynamics of tourism industry performance (Source: developed by the authors)

The index of output performance between tourism industry and innovation activity demonstrates a different picture (Table 2).

\begin{tabular}{|c|c|c|c|c|c|c|c|c|c|c|}
\hline Year / Region & 2012 & 2013 & 2014 & 2015 & 2016 & 2017 & 2018 & 2019 & 2012-2019 & $2015-2019$ \\
\hline Murmansk region & 2.01 & 1.16 & 0.38 & 0.39 & 1.54 & 1.44 & 1.29 & 0.86 & 0.98 & 0.99 \\
\hline Republic of Karelia & 2.12 & 1.50 & 1.50 & 1.15 & 1.11 & 0.49 & 1.04 & 0.38 & 1.02 & 0.75 \\
\hline St.Petersburg & 0.97 & 0.83 & 0.52 & 0.93 & 1.59 & 0.91 & 0.98 & 1.03 & 0.93 & 1.06 \\
\hline Leningrad region & 1.01 & 1.16 & 0.45 & 0.89 & 1.20 & 1.80 & 0.74 & 1.12 & 0.98 & 1.10 \\
\hline Kaliningrad region & 0.79 & 0.67 & 1.59 & 1.19 & 0.35 & 1.16 & 1.38 & 1.03 & 0.93 & 0.93 \\
\hline Pskov region & 0.88 & 0.80 & 1.51 & 1.60 & 0.50 & 0.77 & 0.86 & 0.98 & 0.93 & 0.88 \\
\hline Smolensk region & 0.89 & 0.91 & 0.82 & 0.63 & 1.05 & 1.16 & 0.71 & 1.36 & 0.91 & 0.94 \\
\hline Bryansk region & 0.84 & 0.65 & 1.35 & 0.94 & 0.55 & 0.86 & 1.65 & 1.34 & 0.96 & 0.99 \\
\hline Kursk region & 0.50 & 0.74 & 0.66 & 0.91 & 1.27 & 0.69 & 0.99 & 1.06 & 0.82 & 0.97 \\
\hline Belgorod region & 0.96 & 0.83 & 0.92 & 0.63 & 1.19 & 0.53 & 0.82 & 0.92 & 0.82 & 0.78 \\
\hline Voronezh region & 1.07 & 1.05 & 1.09 & 0.85 & 0.76 & 1.59 & 0.84 & 1.02 & 1.01 & 0.97 \\
\hline Rostov region & 0.95 & 0.67 & 0.77 & 0.83 & 0.64 & 1.03 & 1.43 & 1.54 & 0.94 & 1.04 \\
\hline Krasnodar region & 0.88 & 0.97 & 1.34 & 0.67 & 1.01 & 0.39 & 0.57 & 1.40 & 0.84 & 0.73 \\
\hline Republic of Crimea & - & - & - & - & 0.95 & 0.67 & 1.38 & 1.29 & 1.03 & 1.03 \\
\hline Sevastopol & - & - & - & - & - & - & - & 0.74 & 0.74 & 0.74 \\
\hline Average & 0.99 & 0.89 & 0.90 & 0.85 & 0.90 & 0.88 & 1.00 & 1.02 & 0.93 & 0.93 \\
\hline
\end{tabular}

Table 2. The interdependence of tourism and innovation sectors growth rates by performance (Data source: developed by the authors)

Note: the index is based on the following data: in the numerator are the number of tourist packages sold to the population, the number of people sent on tours, the number of people accommodated in collective accommodation facilities, the number of people accommod ated in sanatorium-resort organizations; in the denominator are the internal costs of research and development, technology development costs, the number of technologies used, the volume of innovative products, the share of innovative products in the GRP. Most of the regions demonstrate disproportion of the faster growth of innovation performance than tourism sector (except the Republic of Karelia and Voronezh region, the high values for the Republic of Crimea and the lowest for Sevastopol are caused by the extremely low values of the primary indicators and the short period of statistic monitoring). For the last 5 years, the proportion between the tourism and innovation activity was 
reached in St. Petersburg, Leningrad and Rostov regions. But in St. Petersburg and Rostov region such trend is mostly due to reduction in innovation performance for the last years, rather than a coherent growth. It is also noticeable that the smallest ratio was in 2015 , just after the geopolitical crisis and sanctions have started, unlike the growth of the number of organizations in the same period (Table 1).

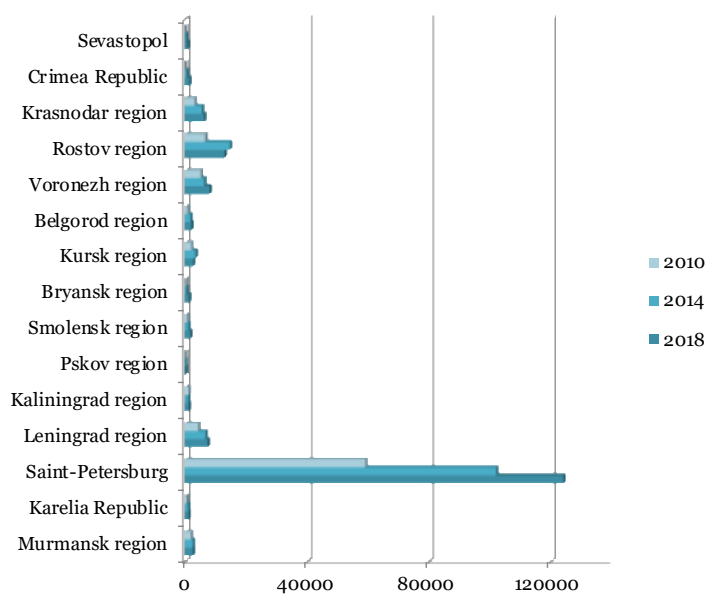

Internal research and development costs, mln rubles

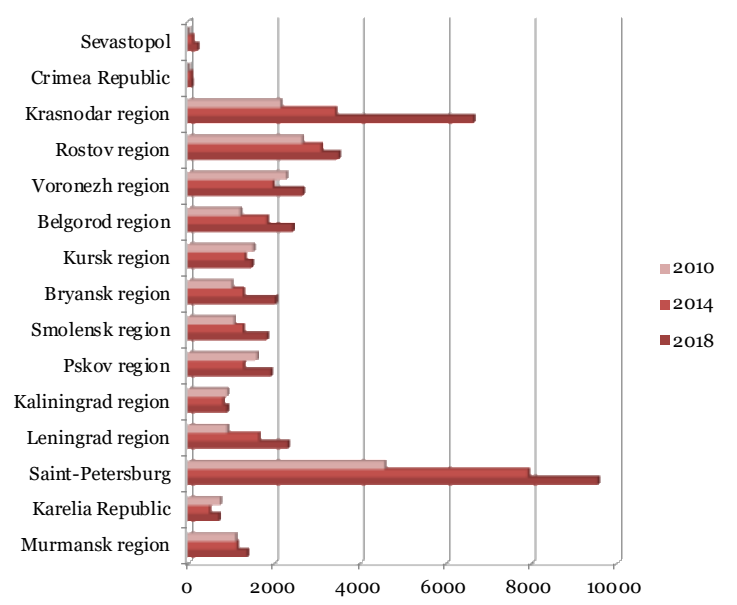

Number of technologies used, units

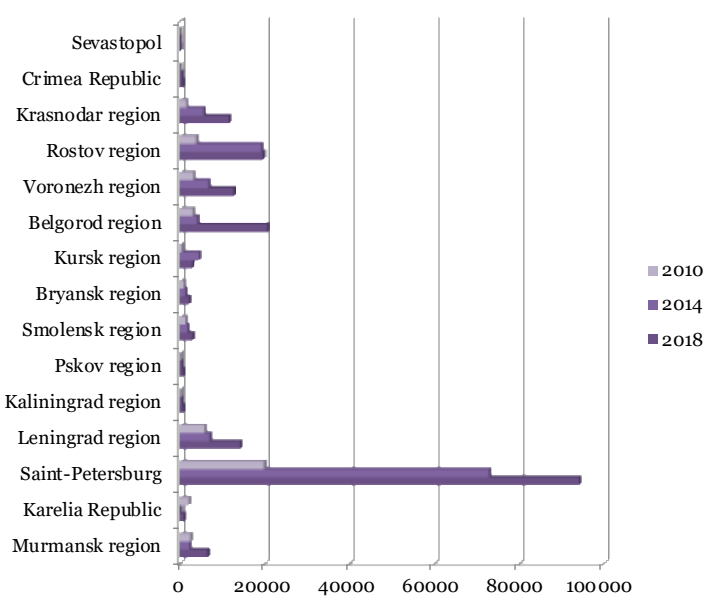

Technology development costs, mln rubles

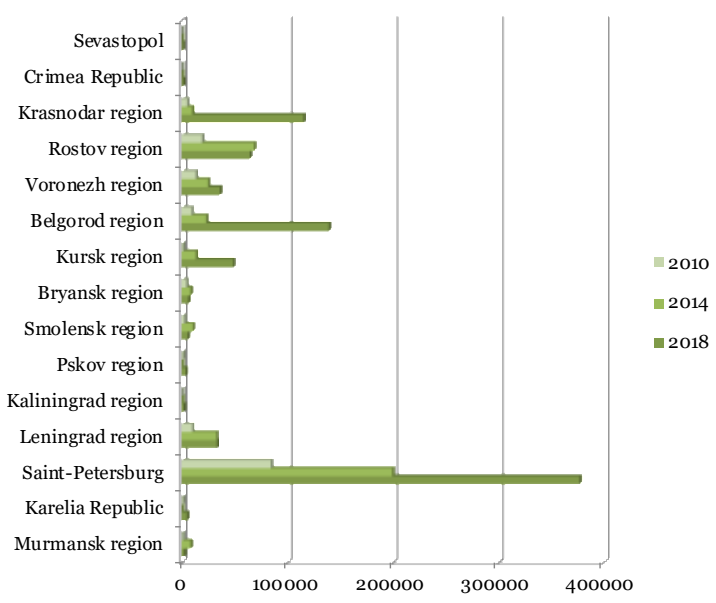

Volume of innovative products, mln rubles

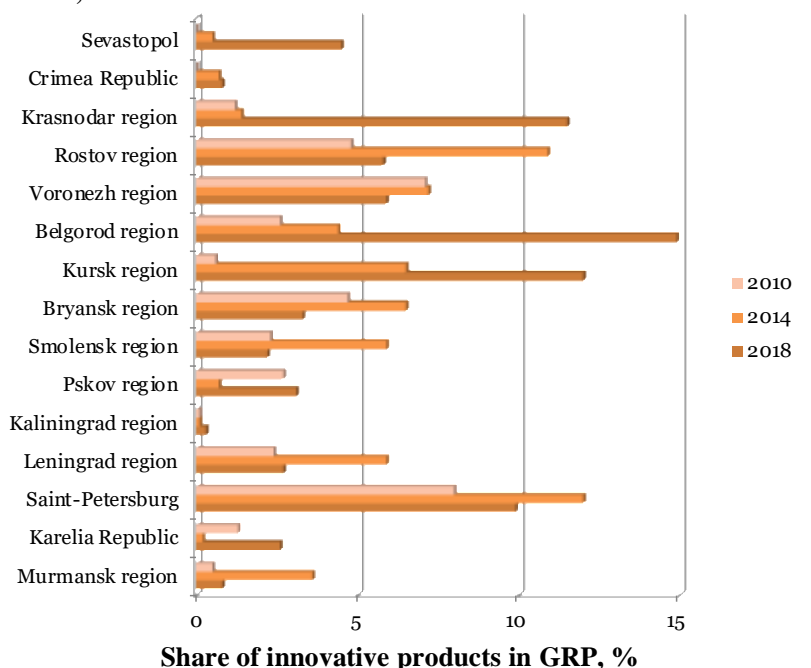

Figure 4. Dynamics of innovation activity (Source: developed by the authors)

The relation of tourism growth to the expenditures on research and technologies was calculated (as such investments can give indirect multiplicative effect for tourism development). This indicator duplicates the previous picture, as most of the regions invest in technologies without multiplication in tourism (Table 3).

Note: the index is based on the following data: in the numerator are growth rates of the number of tour packages sold to the population, the number of people sent on tours, the number of people accommodated in collective accommodation facilities, the number of people accommodated in sanatorium-resort organizations; in the denominator are the growth rates of the technology development costs. The main difference is the higher value of the indicator in 2015 (unlike in all other years) and its modest growth up to 2019. Ge nerally, taking into account the whole period, the investments into technological innovations do not correlate with the tourism industry. The situation 
changes in the recent years. The most extensive effect takes place in Leningrad and Kursk regions, and smaller one in St. Petersburg, Rostov and Bryansk regions, and the Republic of Crimea; the advanced innovation development is observed in the Belgorod region.

\begin{tabular}{|l|c|c|c|c|c|c|c|c|c|c|}
\hline Year / Region & $\mathbf{2 0 1 2}$ & $\mathbf{2 0 1 3}$ & $\mathbf{2 0 1 4}$ & $\mathbf{2 0 1 5}$ & $\mathbf{2 0 1 6}$ & $\mathbf{2 0 1 7}$ & $\mathbf{2 0 1 8}$ & $\mathbf{2 0 1 9}$ & $\mathbf{2 0 1 2 - 2 0 1 9}$ & $\mathbf{2 0 1 5 - 2 0 1 9}$ \\
\hline Murmansk region & 3.61 & 0.98 & 0.46 & 0.57 & 1.88 & 1.34 & 1.31 & 0.19 & $\mathbf{0 . 9 3}$ & $\mathbf{0 . 8 1}$ \\
\hline Republic of Karelia & 2.66 & 2.53 & 2.73 & 2.46 & 0.67 & 0.16 & 1.22 & 0.70 & $\mathbf{1 . 1 9}$ & $\mathbf{0 . 7 4}$ \\
\hline Saint-Petersburg & 0.68 & 0.87 & 0.44 & 0.86 & 1.57 & 0.78 & 1.06 & 1.09 & $\mathbf{0 . 8 6}$ & $\mathbf{1 . 0 4}$ \\
\hline Leningrad region & 0.80 & 0.66 & 0.15 & 9.40 & 0.52 & 3.05 & 0.19 & 3.09 & $\mathbf{0 . 9 6}$ & $\mathbf{1 . 5 5}$ \\
\hline Kaliningrad region & 1.10 & 0.34 & 1.21 & 1.75 & 0.19 & 0.36 & 3.28 & 2.06 & $\mathbf{0 . 8 8}$ & $\mathbf{0 . 9 5}$ \\
\hline Pskov region & 0.66 & 0.48 & 1.55 & 2.15 & 0.72 & 0.31 & 1.53 & 0.87 & $\mathbf{0 . 8 7}$ & $\mathbf{0 . 9 1}$ \\
\hline Smolensk region & 0.62 & 1.30 & 1.03 & 0.72 & 0.60 & 0.92 & 0.81 & 1.44 & $\mathbf{0 . 8 9}$ & $\mathbf{0 . 8 6}$ \\
\hline Bryansk region & 0.73 & 0.55 & 1.26 & 1.60 & 0.79 & 0.57 & 2.06 & 0.82 & $\mathbf{0 . 9 4}$ & $\mathbf{1 . 0 4}$ \\
\hline Kursk region & 0.28 & 0.65 & 0.33 & 1.71 & 4.05 & 0.48 & 1.17 & 0.84 & $\mathbf{0 . 8 2}$ & $\mathbf{1 . 2 6}$ \\
\hline Belgorod region & 1.48 & 1.30 & 1.27 & 0.25 & 2.02 & 0.12 & 0.90 & 1.18 & $\mathbf{0 . 7 9}$ & $\mathbf{0 . 5 8}$ \\
\hline Voronezh region & 0.44 & 1.37 & 0.92 & 1.16 & 0.73 & 1.49 & 0.60 & 1.10 & $\mathbf{0 . 9 1}$ & $\mathbf{0 . 9 7}$ \\
\hline Rostov region & 0.86 & 0.29 & 0.80 & 1.04 & 0.49 & 1.02 & 1.50 & 1.67 & $\mathbf{0 . 8 4}$ & $\mathbf{1 . 0 6}$ \\
\hline Krasnodar region & 0.39 & 0.39 & 0.80 & 3.22 & 0.98 & 0.59 & 0.22 & 4.04 & $\mathbf{0 . 8 2}$ & $\mathbf{1 . 1 1}$ \\
\hline Republic of Crimea & - & - & - & - & 0.91 & 0.76 & 1.47 & 1.12 & $\mathbf{1 . 0 3}$ & $\mathbf{1 . 0 3}$ \\
\hline Sevastopol & - & - & - & - & - & - & - & 0.46 & $\mathbf{0 . 4 6}$ & $\mathbf{0 . 4 6}$ \\
\hline Average & $\mathbf{0 . 8 4}$ & $\mathbf{0 . 7 4}$ & $\mathbf{0 . 8 0}$ & $\mathbf{1 . 4 0}$ & $\mathbf{0 . 8 8}$ & $\mathbf{0 . 6 2}$ & $\mathbf{0 . 9 9}$ & $\mathbf{1 . 0 9}$ & $\mathbf{0 . 8 9}$ & $\mathbf{0 . 9 6}$ \\
\hline
\end{tabular}

Table 3. The interdependence of tourism industry growth to technology development costs (Data source: developed by the authors)

\section{CONCLUSIONS}

The study identified that the co-development of tourism and innovation activity in the western border regions of Russia is moderate. There is the resonance and disproportion in terms of the institutional density of both activities that, however, follow the general economic trends. The general growth in innovation production has not jet reflected in the extensive growth of touristic services, the externalities of investments into research and technologies only starting to be noticeable in several regions in the recent years (Figure 5).

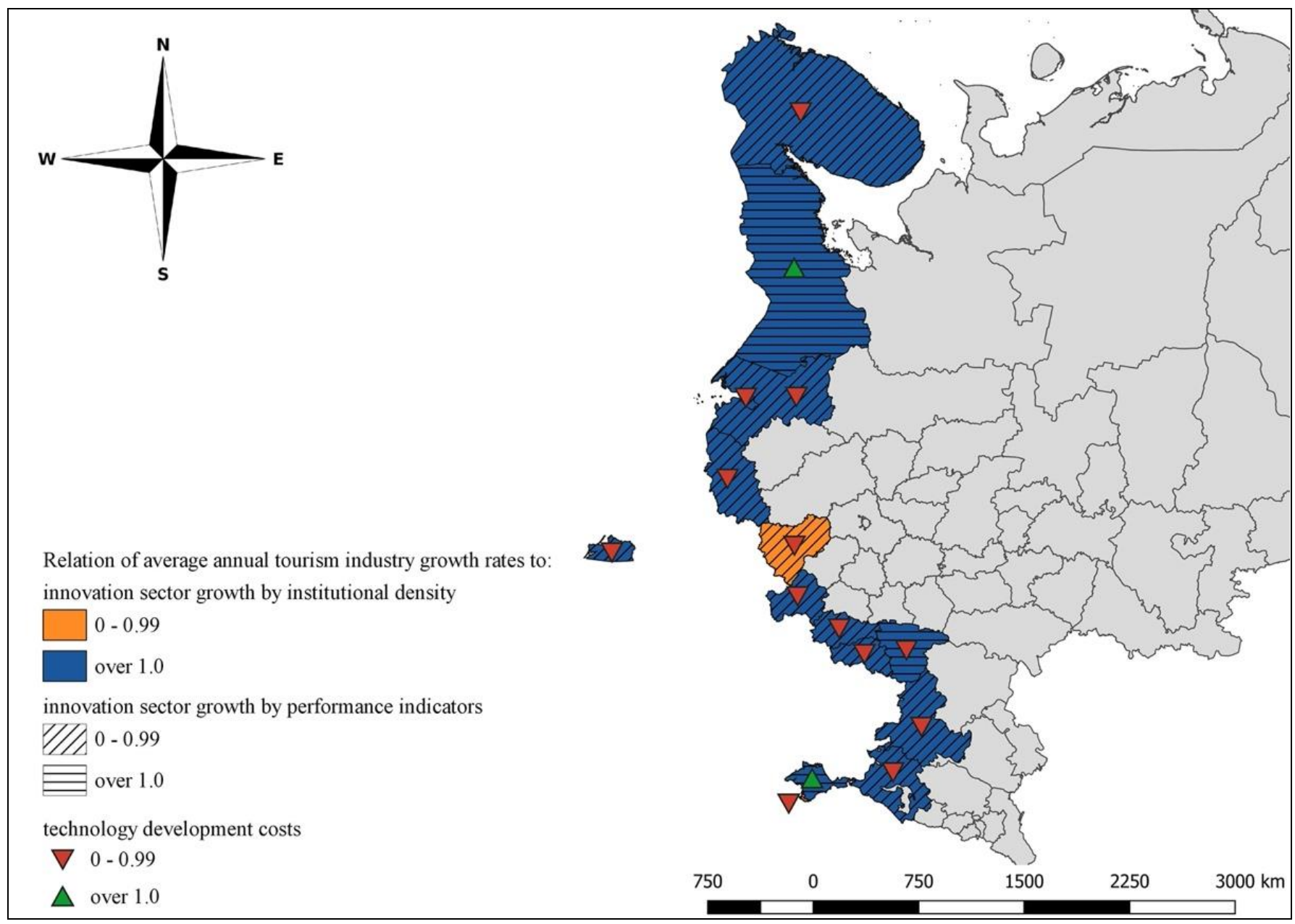

Figure 5. The co-development of tourism industry and innovation activity (Source: developed by the authors)

It means that in the nearest future the growth of demand for innovations can be forecasted in the sphere of tourism, as it needs the qualitative improvements for the further quantitative growth of production. The regions concentrated more on innovations rath er than on tourism (e.g. Belgorod and Kursk regions) can find the new possibilities for attracting touristic flows by implementing innovations to develop infrastructure and create additional objects of interest. Moreover, this could increase the resilience of the regional economy due to diversification and mutual reinforcement (Gorochnaya et al., 2020). 
The research has shown the deepening differentiation between regions. In this situation the newly involved into national organizational and technological space regions of Crimea peninsula need the special attention for achieving stability and proportions in their development, improving infrastructure with the high-scale use of new technologies. Not only the neighboring of central, but also the regional organizations are to participate in this process. The smaller regions in the central zone of the western borderland need crossborder integration to reach functional division of labor in hi-tech sector and activate knowledge spillovers and mutual investments, which can help in enforcing the modest internal potential. The best situation of touristic development at the background of smaller innovative growth is typical for Leningrad region, as it has the externalities of co-location with St. Petersburg and concentrates the parts of its city agglomeration, so that the diffusion of innovations is faster and more intensive. The fact that in the most of regions the performance of touristic sphere's growth is disproportionally slow in relation to innovation one (at the background of parity of organizational growth) marks the cumulative long-term lack of new technologies in touristic sector in the Russian peripheral regions.

They need the intensive and qualitative changes. This lack is partly compensated by the natural potential of the coastal territories and the places of historical and cultural interest that attract tourists, but the further development of the sector needs the radical improvements to gain and maintain national and global competitiveness.

\section{Acknowledgments}

The study was funded by RFBR according to the research project No. 19-010-01083 "Problems of Innovation Security and Mechanisms of Cluster Economic Development of the Border Regions of the European Part of Russia". V.V. Gorochnaya is grateful to the Russian Academic Excellence Project at the Immanuel Kant Baltic Federal University. A.S. Mikhaylov acknowledges the support of the IG RAS project No. 0148-2019-0008 "Problems and prospects of Russia's territorial development in the context of its unevenness and global instability". The research part of A.A. Mikhaylova was carried out within the framework of project 5-100 No. 2 "Innovation development trajectory transformation of Russian regions in the context of the 2020 pandemic".

\section{REFERENCES}

Assaf, A., \& Scuderi, R. (2020). COVID-19 and the recovery of the tourism industry. Tourism Economics, 26(5), 731-733. https://doi.org/10.1177/1354816620933712

Brandão F., Costa C., \& Buhalis D. (2018). Tourism innovation networks: A regional approach. European Journal of Tourism Research, 18 (1), $33-56$.

Brandão, F., Breda, Z., \& Costa, C. (2019). Innovation and internationalization as development strategies for coastal tourism destinations: The role of organizational networks. Journal of Hospitality and Tourism Management, 41, 219-230. https://doi.org/10.1016/j.jhtm.2019.10.004

Gomezelj, D.O. (2016). A systematic review of research on innovation in hospitality and tourism. International Journal of Contemporary Hospitality Management, 28 (3), 516-558. https://doi.org/10.1108/IJCHM-10-2014-0510

Gorochnaya, V.V., Mikhaylov, A.S., Mikhaylova, A.A., \& Plotnikova, A.P. (2020). Tourism clusters and innovation security: Dialectics in the western border regions of Russia. Geojournal of Tourism and Geosites, 28(1), 127-139. https://doi.org/10.30892/gtg.28110-457

Happ, E., \& Ivancsóné Horváth, Z. (2020). A study of digital marketing tools usage habits among Hungarian tourists. Geojournal of Tourism and Geosites, 32 (4), 1283-1289. https://doi.org/10.30892/GTG.32414-570

Hoarau, H. (2014). Knowledge acquisition and assimilation in tourism-innovation processes. Scandinavian Journal of Hospitality and Tourism, 14 (2), 135151. https://doi.org/10.1080/15022250.2014.887609

Kolosov, V.A., Zotova, M.V., \& Sebentsov, A.B. (2016). The barrier function of Russia's borders. Regional Research of Russia, 6 (4), $387-397$.

Lejárraga, I., \& Walkenhorst, P. (2013). Economic policy, tourism trade and productive diversification. International Economics, 135-136, 1-12. https://doi.org/: 10.1016/j.inteco.2013.09.001

Makkonen, T., Williams, A.M., Weidenfeld, A., \& Kaisto, V. (2018). Cross-border knowledge transfer and innovation in the European neighbourhood: Tourism cooperation at the Finnish-Russian border. Tourism Management, 68, 140-151. https://doi.org/10.1016/j.tourman.2018.03.008

Mauri, C., \& Turci, L. (2018). From ski to snow: Rethinking package holidays in a winter mountain destination. Worldwide Hospitality and Tourism Themes, 10(2), 201-210. https://doi.org/10.1108/WHATT-12-2017-0076

Mikhaylov, A.S., Wendt, J.A., Peker, I.Y., \& Mikhaylova, A.A. (2020). Spatio-temporal patterns of knowledge transfer in the borderland. Baltic Region, Vol. 12(1), 132-155. https://doi.org/10.5922/2079-8555-2020-1-8

Nilsson, J., Eskilsson, L., \& Ek, R. (2010). Creating cross-border destinations: INTERREG programmes and regionalisation in the Baltic Sea area. Scandinavian Journal of Hospitality and Tourism, 10 (2), 153-172. https://doi.org/10.1080/15022250903561978

Ozseker, D.B. (2019). Towards a model of destination innovation process: An integrative review. Service Industries Journal, 39 (3-4), 206-228. https://doi.org/10.1080/02642069.2018.1491970

Panfiluk, E. (2021). Innovativeness of tourism enterprises: Example of Poland. Sustainability (Switzerland), 13(3), 1-17. https://doi.org/10.3390/su13031024

Pikkemaat, B., Peters, M., \& Bichler, B.F. (2019). Innovation research in tourism: Research streams and actions for the future. Journal of Hospitality and Tourism Management, 41, 184-196. https://doi.org/10.1016/j.jhtm.2019.10.007

Rajčáková, E., \& Švecová, A. (2013). Cross-border cooperation in Slovak-Czech border region under EU programmes. European Countryside, 5 (2), $133-145$. https://doi.org/10.2478/euco-2013-0009

Romão, J. (2020). Tourism, smart specialisation, growth, and resilience. Annals of Tourism Research, 84, 102995. https://doi.org/10.1016/j.annals.2020.102995

Scott, N., Cooper, C., \& Baggio, R. (2008). Destination networks: Four Australian cases. Annals of Tourism Research, 35 (1), 169-188. https://doi.org/ 10.1016/j.annals.2007.07.004

Sigurardottir, I., \& Steinthorsson, R.S. (2018). Development of micro-clusters in tourism: A case of equestrian tourism in northwest Iceland. Scandinavian Journal of Hospitality and Tourism, 18 (3), 261-277. https://doi.org/10.1080/15022250.2018.1497286

Sundbo, J., Orfila-Sintes, F., \& Sørensen, F. (2007). The innovative behaviour of tourism firms-Comparative studies of Denmark and Spain. Research Policy, 36, 88-106.

Vaishar, A., Dvořák, P., Hubačíková, V., \& Zapletalová, J. (2013). Contemporary development of peripheral parts of the Czech-Polish borderland Geographia Polonica, 86 (3), 237-252. https://doi.org/10.7163/GPol.2013.21

Verreynne, M., Williams, A.M., Ritchie, B.W., Gronum, S., \& Betts, K.S. (2019). Innovation diversity and uncertainty in small and medium sized tourism firms. Tourism Management, 72, 257-269. https://doi.org/10.1016/j.tourman.2018.11.019

Vorobiova, N., Pinto, P., Pintassilgo, P., \& Lavandoski, J. (2019). Motivations of tourists in wine regions: The case of la rioja, Spain. International Journal of Wine Business Research, 32 (3), 353-371. https://doi.org/10.1108/IJWBR-02-2019-0014

Weidenfeld, A. (2013). Tourism and cross border regional innovation systems. Annals of Tourism Research, 42, 191-213. https://doi.org/10.1016/j.annals.2013.01.003

Weidenfeld, A. (2018). Tourism diversification and its implications for smart specialization. Sustainability, 10 (2), 319.

Zach, F.J., \& Hill, T.L. (2017). Network, knowledge and relationship impacts on innovation in tourism destinations. Tourism Management, 62, 196-207. https://doi.org/10.1016/j.tourman.2017.04.001

*** UNWTO (2021). UNWTO World Tourism Barometer (English version), 19 (1). https://doi.org/10.18111/wtobarometereng

*** World Travel \& Tourism Council (2020). Travel \& Tourism - Global Economic Impact \& Trends 2020. URL: https://wttc.org/Research/Economic-Impact 